\title{
Axianassa australis Rodrigues and Shimizu, 1992 (Crustacea: Decapoda: Gebiidea: Axianassidae): First record from Sergipe, NE Brazil
}

\author{
Leonardo C. Rosa ${ }^{1 *}$ and Alexandre O. Almeida ${ }^{2}$ \\ 1 Universidade Federal de Sergipe, Núcleo de Engenharia de Pesca. Av. Marechal Rondon, s/n. CEP 49100-000. São Cristóvão, SE, Brazil. \\ 2 Universidade Estadual de Santa Cruz, Departamento de Ciências Biológicas. Rodovia Jorge Amado, km 16. CEP 45662-900. Ilhéus, BA, Brazil. \\ * Corresponding author. E-mail: leonardo.rosa@rocketmail.com
}

\begin{abstract}
The western Atlantic mud-shrimp Axianassa australis Rodrigues and Shimizu, 1992 (Crustacea: Decapoda: Gebiidea: Axianassidae), known from Florida, Gulf of Mexico and Brazil, is firstly recorded from the state of the Sergipe, NE Brazil, filling a gap in the species distribution along Brazilian coast.
\end{abstract}

Mud-shrimps genus Axianassa Schmitt, 1924 are mainly characterized by their carapace with well-defined linea thalassinica and cervical groove, short rostrum anteriorly rounded, weakly to moderately developed, reaching well beyond cornea of eyes, body poorly calcified and abdomen with thin walls (Kensley and Heard 1990; Melo et al. 2006; Anker 2010; Liu and Liu 2010). Presently, eight species are known from tropical and subtropical waters of western Atlantic (A. intermedia Schmitt, 1924; $A$. arenaria Kensley and Heard, 1990; A. jamaicensis Kensley and Heard, 1990 and A. australis Rodrigues and Shimizu, 1992), eastern Pacific (A. mineri Boone, 1931 and A. canalis Kensley and Heard, 1990), Indo-West Pacific (A. ngochoae Anker, 2010) and west Pacific (A. sinica Liu and Liu, 2010) (Kensley and Heard 1990; Anker 2010; Liu and Liu 2010).
The type locality of $A$. australis (Figure 1) is "Fazenda Maricultura" ("Maricultura da Bahia"), located in Valença, central coast of the state of Bahia, Brazil (Rodrigues and Shimizu 1992). The species has been recorded from Florida, Gulf of Mexico, and Brazil (states of Pernambuco, Bahia, São Paulo and Paraná) (Rodrigues and Shimizu 1992; Melo 1999; Felder 2001; Melo et al. 2006; Coelho et al. 2007). Specimens of $A$. australis typically burrow complex galleries among coastal mangroves and adjacent mud flats, and are apparently adapted to strongly hypoxic and reduced (sulfidic) environments (Dworschak and Rodrigues 1997; Felder 2001).

On July 2010, one individual of $A$. australis [male with $3.5 \mathrm{~mm}$ in carapace length (CL)] was caught with a PVC corer $(10 \mathrm{~cm}$ of diameter and inserted $20 \mathrm{~cm}$ depth into

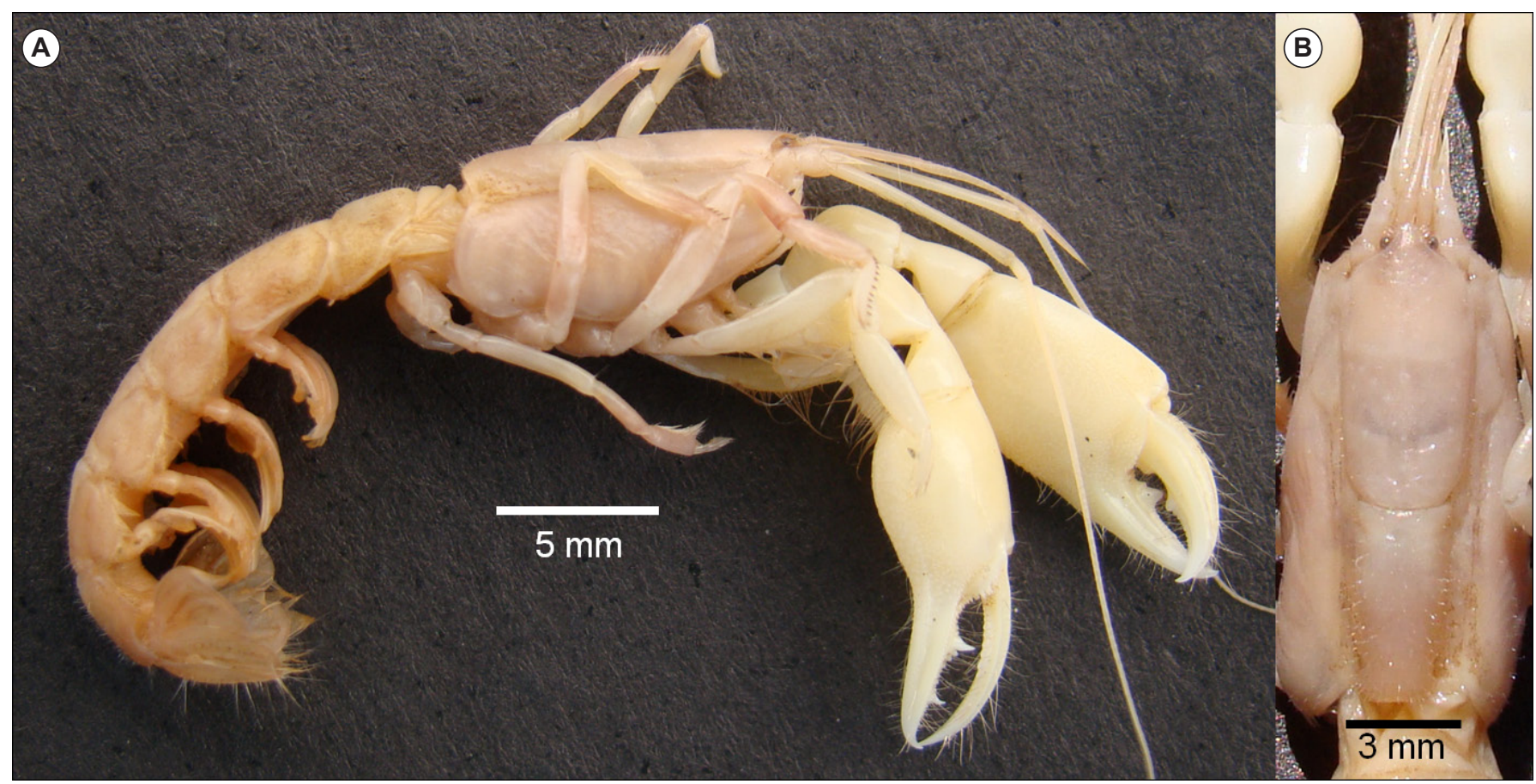

FIGURE 1. Axianassa australis Rodrigues and Shimizu, 1992: male collected in the estuary of Real River, state of Sergipe, Brazil (NEP-CRUST 0004). (a) Lateral view of whole specimen; (b) dorsal view of carapace. 
sediment) during a benthic survey carried out nearby an oyster farm situated at the estuary of São Francisco River, northern state of Sergipe, NE Brazil (10³2'01"S; $36^{\circ} 29^{\prime} 36^{\prime \prime} \mathrm{W}$ ) (Figure 2). In this place, the water salinity ranged from 23 to 34 and sediment was composed mainly by poorly sorted fine sand with $1.25 \%$ of fine fractions (i.e., silt + clay) and $7.58 \%$ of organic matter content. One year later, other 10 individuals, 4 males ranging from 5.2 to 10.3 $\mathrm{mm}$ CL and 6 females (four of which ovigerous) ranging from 6.7 to $14.0 \mathrm{~mm} \mathrm{CL}$, were caught using a "yabby-pump" (Hailstone and Stephenson 1961) on a sandy-muddy tidal flat located at the estuary of Real River, southern Sergipe (11 $\left.{ }^{\circ} 28^{\prime} 40^{\prime \prime} \mathrm{S} ; 3^{\circ} 23^{\prime} 55^{\prime \prime} \mathrm{W}\right)$ (Figure 2). Our material agrees with the original description by Rodrigues and Shimizu (1992).

The present record of $A$. australis represents the first from the state of Sergipe, filling a gap in the species distribution along the Brazilian coast between the states of Pernambuco and Bahia. Voucher specimens were fixed in formaldehyde $5 \%$ and deposited in the

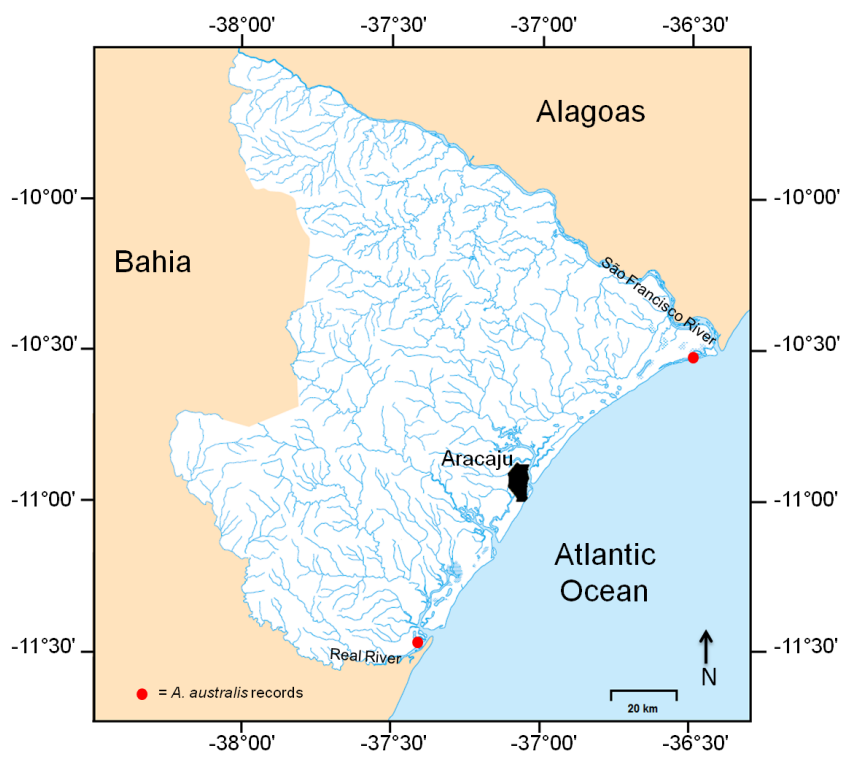

FIGURE 2. Hydrological basins of the state of Sergipe, Brazil, indicating the sites where the mud-shrimp Axianassa australis Rodrigues and Shimizu, 1992 was collected (red circles). carcinological collection of the Universidade Estadual de Santa Cruz (UESC 1529), in Ilhéus, Bahia, Brazil, and in the carcinological collection of the Núcleo de Engenharia de Pesca (NEP-CRUST 0002; 0004-0012), Universidade Federal de Sergipe, São Cristóvão, Sergipe, Brazil. Samples were collected with the permits of the Instituto Chico Mendes de Conservação da Biodiversidade (ICMBio) and Sistema de Autorização e Informação em Biodiversidade (SISBIO), license number 32380-1.

\section{LITERATURE Cited}

Anker, A. 2010. The mud-shrimp genus Axianassa Schmitt, 1924 (Crustacea, Decapoda, Axianassidae) in the Indo-West Pacific, with description of a new species from French Polynesia. Zootaxa 2557: 49-59.

Coelho, P.A., A.O. Almeida, L.E.A. Bezerra and J.F. Souza-Filho. 2007. An updated checklist of decapod crustaceans (infraorders Astacidea, Thalassinidea, Polychelida, Palinura, and Anomura) from the northern and northeastern Brazilian coast. Zootaxa 1519: 1-16.

Dworschak, P.C. and S.A. Rodrigues. 1997. A modern analogue for trace fossil Gyrolithes: burrows of the thalassinidean shrimp Axianassa australis. Lethaia 30: 41-52.

Felder, D.L.. 2001. Diversity and ecological significance of deep-burrowing macrocrustaceans in coastal tropical waters of the Americas (Decapoda: Thalassinidea). Interciencia 26: 440-449.

Hailstone, T.S. and W. Stephenson. 1961. The biology of Callianassa (Trypaea) australiensis Dana, 1852 (Crustacea, Thalassinidea). University of Queensland Papers 1(12): 259-285.

Kensley, B. and R. Heard. 1990. The genus Axianassa (Crustacea: Decapoda: Thalassinidea) in the Americas. Proceedings of the Biological Society of Washington 103: 558-572.

Liu, W. and J.Y. Liu. 2010. First record of the gebiidean genus Axianassa Schmitt, 1924 (Crustacea: Decapoda: Gebiidea: Axianassidae) in the west Pacific, with description of a new species from the South China Sea. The Ruffles Bulletin of Zoology 58(2): 193-197.

Melo, G.A.S. 1999. Manual de identificação dos Crustacea Decapoda do litoral brasileiro: Anomura, Thalassinidea, Palinuridea, Astacidea. São Paulo: Plêiade. 551 p.

Melo, S.G., J. Loyola e Silva and S. Masunari. 2006. First report of Axianassa australis Rodrigues \& Shimizu (Crustacea: Decapoda: Thalassinidea) along the coast of the state of Paraná, Brazil. Acta Biológica Paranaense 35(1-2): 83-88.

Rodrigues, S.A. and R.M. Shimizu. 1992. Description of a new Axianassa (Crustacea: Decapoda: Thalassinidea) from Brazil, and its first larval stage. Proceedings of the Biological Society of Washington 105(2): 317-323.

RECEIVED: July 2012

ACCEPTED: August 2012

Published online: December 2012

EDITORIAL RESPONSIBILITY: Luis Ernesto Arruda Bezerra 